\title{
Feeding Overstrength Cows' Milk to Babies
}

\author{
B. A. M. SMITH
}

British Medical fournal, 1974, 4, 741-742

\section{Summary}

The dangers of overstrength milk feeds have been emphasized in several reports during the last two years. They may even be a factor in unexpected death in infants. Samples of prepared dried milk feeds were obtained from 302 mothers who brought their 5- to 8-week-old infants to a special follow-up clinic. Determination of the sodium content of the milk indicated that $57 \%$ of the feeds were significantly overstrength. There is an urgent need to improve mothers' knowledge of the importance of preparing dried cows' milk infant feeds correctly.

\section{Introduction}

A retrospective study on Sheffield cot deaths in 1963-72 showed that infants who died had certain perinatal characteristics which differed significantly from those of control infants (Protestos et al., 1973). A two-year survey is in progress to test the value of criteria derived from these perinatal factors in detecting on the first day after birth infants with an increased risk of morbidity and mortality. Full details of the perinatal criteria used will be published when the survey is completed. As part of this study a group of Sheffield infants born in 1973 were seen once at a special paediatric clinic when between 5 and 8 weeks of age. A feeding history was taken, a full clinical examination was made, and with their mothers' permission the infants' blood urea was measured. The present report concerns the findings of the first 353 infants that were seen. These babies were selected to test the predictive value of our perinatal criteria and might not have been fully representative of the Sheffield infant population. The frequency with which these infants were being fed with a significantly overstrength dried cows'-milk formula and had high blood urea levels, however, provoked us to an increased effort to improve the mothers' knowledge of the importance of correct preparation of dried milk feeds.

\section{Methods}

Of the 353 infants 318 were fed on an unmodified dried cows' milk formula. (Five infants fed on national dried milk and one infant fed on an evaporated milk were excluded.) The mothers were asked to bring a prepared milk feed with them "in case the baby required a feed while they were at the clinic." They were not warned that a specimen of milk would be requested and examined. Altogether 302 mothers gave a specimen of dried milk (235 Full Cream Cow and Gate, 67 Ostermilk No. 2). The sodium content of the milk was determined as an indicator of the prepared milk's correct strength or otherwise. Samples of milks prepared according to the manufacturers' instructions in the milk kitchen of the hospital which were examined in our laboratory had a sodium content of $22 \mathrm{mmol} / 1$.

Children's Hospital, Sheffield S10 2TH

B. A. M. SMITH, M.B., M.R.C.P., Consultant Paediatrician

\section{Results}

The sodium contents of the 302 milk specimens obtained are shown in table I. Any milk having a sodium content of over

TABLE I-Distribution of Sodium Content of Prepared Dried Milk Feeds

\begin{tabular}{|c|c|c|c|c|c|}
\hline $\begin{array}{l}\mathrm{Na}(\mathrm{mmol} / \mathrm{l}) . \\
\mathrm{No}(\%) \text { of cases }\end{array}$ & $\begin{array}{c}15-18 \\
33(10.9)\end{array}$ & $\begin{array}{c}19-24 \\
97(32 \cdot 1)\end{array}$ & $\begin{array}{c}25-29 \\
80(26 \cdot 5)\end{array}$ & $\begin{array}{c}30-34 \\
56(18.5)\end{array}$ & $\begin{array}{c}35-39 \\
24(7 \cdot 9)\end{array}$ \\
\hline
\end{tabular}

$24 \mathrm{mmol} / 1$. was regarded as significantly overstrength.

On this criteria $57 \%$ of prepared dried milk feeds were significantly overstrength. Only $83(27.5 \%)$ milk feeds had a sodium content of $22 \mathrm{mmol} / \mathrm{l}$. or less. Therefore $219(72.5 \%)$ could be regarded as overstrength. The highest milk sodium level recorded was $64 \mathrm{mmol} / 1$. - three times overstrength. Significantly understrength feeds were rare.

In addition to milk 159 mothers were in the habit of offering their artificially fed infants water to drink each day. The amounts were variable but often extremely small (less than $28.4 \mathrm{ml}$ ). Of the 353 infants 107 were receiving cereal by the age of five weeks. Only 22 infants were receiving strained food by the time they attended the clinic.

\section{BLOOD UREA LEVELS}

The blood urea levels of 317 of the 318 infants receiving an unmodified dried cows' milk formula are shown in table II. The

TABLE II-Blood Urea Levels in 317 Infants receiving Unmodified Dried Cows' Milk Formula

\begin{tabular}{cc|c|c|c|c|c}
\hline $\begin{array}{c}\text { Blood urea in } \\
\mathrm{mg} / 100 \mathrm{ml} .\end{array}$ & & $<40$ & $40-49$ & $50-59$ & $60-69$ & $\geqslant 70$ \\
$\begin{array}{c}\text { (mmol/1.) } \\
\text { No. (=) of cases }\end{array}$ & $\cdots$ & $\begin{array}{c}(<6 \cdot 6) \\
28(8 \cdot 8)\end{array}$ & $\begin{array}{c}(6 \cdot 6-8 \cdot 1) \\
91(28 \cdot 7)\end{array}$ & $\begin{array}{c}(8 \cdot 3-9 \cdot 8) \\
124(39 \cdot 1)\end{array}$ & $\begin{array}{c}(10-11 \cdot 5) \\
57(18 \cdot 0)\end{array}$ & $\begin{array}{c}(\geqslant 11 \cdot 6) \\
17(5 \cdot 4)\end{array}$ \\
\hline
\end{tabular}

mean blood urea level of these infants was $8.6 \mathrm{mmol} / 1$. (range $3.3-13.5 \mathrm{mmol} / \mathrm{l}$.). It can be seen that $23 \%$ of the infants had a blood urea level over $10 \mathrm{mmol} / \mathrm{l}$.

The mean blood urea level in the 14 entirely breast-fed infants seen was $3.2 \mathrm{mmol} / 1$. (range $1.8-4.5 \mathrm{mmol} / 1$.). The difference in the blood urea levels between the breast-fed infants and those receiving an unmodified dried cows' milk formula was highly significant $(P=0.005)$.

The mean blood urea level in 15 survey infants receiving a modified artificial milk-that is, one with a reduced protein and mineral content-was $4.2 \mathrm{mmol} / 1$. (range $2-5.8 \mathrm{mmol} / 1$.). The difference in the blood urea levels between infants who were fed on a modified milk and those receiving an unmodified dried milk formula was again highly significant $(P=0.005)$.

\section{EFFECT OF ADVICE BY MIDWIFE IN LYING-IN WARD}

It is customary to give the mother who is bottle feeding her baby instructions on feed preparation while she is in the lying-in ward. In one of the maternity units in Sheffield the midwives were asked to include in their instructions a specific warning about the dangers of overstrength feeds. Subsequently specimens of milk were obtained when the mother brought her baby 
to the special clinic. The distribution of feed strengths obtained from bottle-fed infants delivered in this unit before and after this warning had been introduced is shown in table III.

TABLE III-Sodium Content of Prepared Milk Feeds Before and After Specific Warning was given to Mothers about Dangers of Overstrength Feeds. Results are Numbers of Cases.

\begin{tabular}{|c|c|c|c|c|c|c|c|}
\hline $\mathrm{Na}(\mathrm{mmol} / \mathrm{l})$. & $15-18$ & $19-24$ & $25-29$ & $30-34$ & $35-39$ & $\geqslant 40$ & Total \\
\hline $\begin{array}{l}\text { Before } \\
\text { After }\end{array}$ & $\begin{array}{l}7 \\
7\end{array}$ & $\begin{array}{l}18 \\
15\end{array}$ & $\begin{array}{l}18 \\
11\end{array}$ & $\begin{array}{l}13 \\
13\end{array}$ & $\begin{array}{l}7 \\
1\end{array}$ & $\begin{array}{l}7 \\
1\end{array}$ & $\begin{array}{l}70 \\
48\end{array}$ \\
\hline
\end{tabular}

This method of advising mothers was generally disappointing, and over half the infants whose mothers had received the specific warning were still receiving overstrength feeds.

\section{EFFECT OF VISIT BY HEALTH VISITOR}

The 92 mothers producing a dried milk feed with a sodium concentration over $30 \mathrm{mmol} / \mathrm{l}$. were visited by a health visitor and carefully reinstructed on the correct preparation of the milk feed. Without prior warning a milk sample was obtained on a subsequent routine home visit by the health visitor. It was possible to obtain a further specimen from only 58 mothers. Of the specimens nine were more overstrength than the first specimen; 47 were weaker but 19 of these were still overstrength -that is, sodium content was over $24 \mathrm{mmol} / 1$. Only 30 out of the 58 were producing a milk of correct strength after careful reinstruction in the home.

\section{Discussion}

The artificially fed infants seen seemed clinically healthy but had a mean blood urea level of $8.6 \mathrm{mmol} / 1$. Even more disturbing is the fact that $23 \%$ had blood urea levels over $10 \mathrm{mmol} / 1$. and $5 \%$ of the infants had blood urea levels over $11.6 \mathrm{mmol} / 1$. In this group of infants $57 \%$ were receiving a feed which was significantly stronger than intended and in $30 \%$ the feed was $40 \%$ over strength as judged by its salt content.

Davis and Saunders (1973) have previously drawn attention to the raised blood urea levels found in artificially fed infants. While there is no direct evidence that these levels of urea are of themselves actually harmful to the baby general experience of the effects of illness in children suggests that such infants would have a reduced reserve to any increase in their extrarenal water needs such as occurs in gastroenteritis and other infective illnesses.

The high incidence of hypertonic dehydration occurring in infants admitted to hospital with gastroenteritis and other infective illnesses has caused paediatricians much concern
(Ironside et al., 1970; Finberg, 1973). Taitz and Byers (1972) have drawn attention to the frequency with which overstrength dried milk formulae were fed to infants and the likely relationship of this to hypernatraemic dehydration. Permanent neurological damage can result from these hyperosmolar states (Macaulay and Watson, 1967; Morris-Jones et al., 1967). Recently, Emery et al. (1974) have suggested that this form of electrolyte disturbance may play a part in sudden infant death. Using the chemical study of vitreous humour they showed in a sequential series of 40 infants found unexpectedly dead at home that about half were in a state of severe hypernatraemic uraemia. While these authors do not imply that hypernatraemic uraemia was the precise cause of death it was undoubtedly a factor in the infant's illness and death. Thus the dangers of overstrength dried milk feeds are apparent. The results of this survey indicate the frequency with which overstrength dried cows' milk formula is being fed to infants in the first weeks after birth. Urgent action is needed to improve infant feeding practices.

In Sheffield we are attempting to improve mothers' knowledge of the importance of correct infant feeding. In particular, we are emphasizing the advantages of breast feeding and the dangers of overstrength artificial feeds. It seems clear from our results that the usual methods of instructing mothers in maternity units during the lying-in period and in their homes after discharge are insufficient. Many mothers who are bottle feeding their infants continue to produce overstrength dried milk feeds even when their midwives and health visitors have included a specific warning of this danger.

We are trying additional methods of advising and instructing mothers. Our survey of Sheffield infants continues to include a check on the strength of the dried milk feeds being prepared for them. This will enable us to judge whether or not our methods are successful.

I thank the health visitors working on this survey-Mrs. N. Lockwood, Mrs. B. Owen, Mrs. J. Battye, Mrs. M. Canty, Mrs. D. Whitehead, Miss M. Portess, and Miss M. Ward. This survey is in part funded by the Foundation for the Study of Infant Deaths.

\section{References}

Davies, D. P., and Saunders, R. R. (1973). Archives of Disease in Childhood, 48,563 .

Emery, J. L., Worthy, E., and Swift, P. (1974). Archives of Disease in Childhood, 49, 686 .

Finberg, L. (1973). New England fournal of Medicine, 289, 196.

Ironside, A. G., Tuxford, A. F., and Heywater, B. (1970). British Medical

Journal, 3, 20.
Macaulay, D., and Watson, M. (1967). Archives of Disease in Childhood, 42, 485 .

Morris-Jones, P. H., Houston, I. B., and Evans, R. C. (1967). Lancet, 2, 1385.

Protestos, C. D., et al. (1973). Archives of Disease in Childhood, 48, 835.

Taitz, L. S., and Byers, H. D. (1972). Archives of Disease in Childhood, 47 257. 